\title{
Microsatellites from the vairone Leuciscus souffia (Pisces: Cyprinidae) and their application to closely related species
}

\author{
FRAUKE M. MUENZEL, MATTHIAS SANETRA, WALTER SALZBURGER* and AXEL MEYER \\ Lehrstuhl für Zoologie und Evolutionsbiologie, Department of Biology, University of Konstanz, Universitätsstrasse 10, 78457 \\ Konstanz, Germany
}

\begin{abstract}
Eleven microsatellites were isolated from the vairone Leuciscus souffia (Risso 1826), an endangered fish that inhabits river systems in and around the Alps in Europe. The level of genetic diversity was assessed in 29 individuals of the subspecies L. s. souffia, and their variability was further estimated in seven individuals of a different subspecies, L. s. muticellus. Eight of these microsatellite loci were also applied to seven closely related cyprinid species. Availability of the reported microsatellite loci will facilitate the investigation of population genetic structure of these species with applications for the development of conservation strategies and phylogeographical approaches.
\end{abstract}

Keywords: conservation, freshwater fish, genetic diversity, Leuciscus souffia, microsatellites, population genetics

Cyprinids are the most species-rich family of freshwater fishes in the Northern Hemisphere with a relatively uniform fauna in Central Europe. Since they are restricted to river and lake drainage systems, their distribution closely reflects their biogeographical history (Zardoya \& Doadrio 1999). Therefore, cyprinids are appropriate model organisms to understand evolutionary mechanisms that drive the diversification and distribution of species. The vairone, Leuciscus souffia (Risso 1826), is a rather small cyprinid that inhabits the upper reaches of rivers in and around the Alps. Two subspecies are currently recognized: L. s. souffia in Alpine regions and north of the Alps and L. s. muticellus in Italy. Research on the vairone has so far focused on phylogeographical and taxonomic questions and was based on morphological characters, allozymes and mitochondrial DNA (Gilles et al. 1998; Salzburger et al. 2003; Salducci et al. 2004). Current research now focuses on the fine-scale genetic structure of the vairone on a smaller geographical scale to determine in more detail how genetic variability patterns relate to environmental processes. The faster evolving microsatellite markers will provide insights into

Correspondence: Axel Meyer, Fax: +49-(0)7531-883018;

E-mail: axel.meyer@uni-konstanz.de

*Present address: Department of Ecology and Evolution, University of Lausanne, Le Biophore, 1015 Lausanne, Switzerland finer levels of population structure and, possibly hybridization, also in related species.

A partial genomic library enriched for microsatellites was constructed using the methods described by Tenzer et al. (1999) and later modified by Garner et al. (2000). Using standard phenol-chloroform methods (Sambrook et al. 1989), genomic DNA was extracted from one individual of L. s. souffia, and $30 \mu \mathrm{g}$ was digested with the restriction enzyme MboI. Fragments ranging from 400 to 900 base pairs (bp) were ligated to specific linkers (Er1Bh1GATCSticky: 5'-GATCGGCAGGATCCACTGAATTCGC-3' and Er1Bh1Blunt: 5'-GCGAATTCAGTGGATCCTGCC-3'). Prehybridization polymerase chain reaction (PCR) amplification was performed for 15 cycles using one of the linker oligos. For enrichment, linked fragments were denatured and hybridized to $3^{\prime}$ biotinylated $(\mathrm{CA})_{15}$ and $(\mathrm{CT})_{15}$ probes in $10 \times \mathrm{SSC} / 0.2 \% \mathrm{SDS}$ for $3 \mathrm{~h}$ at $55^{\circ} \mathrm{C}$. Using streptavidin magnetic beads (DynaBeads M-280 Streptavidin) with several washes (twice in $2 \times \mathrm{SSC} / 0.2 \%$ SDS at room temperature, twice in $2 \times \mathrm{SSC} / 0.1 \%$ SDS at $55^{\circ} \mathrm{C}$, and once in $1 \mathrm{M} \mathrm{TE} / 50 \mathrm{~mm} \mathrm{NaCl}$ at room temperature), the DNA that hybridized to the probe was separated. Microsatelliteenriched DNA was then PCR-amplified for 20 cycles, cloned into the Invitrogen pCRII TOPO vector and transformed into chemically competent Escherichia coli cells supplied with the TOPO TA Cloning Kit. Cells were grown on 
ampicillin-treated agar plates from which individual colonies were picked and regrown for 6-8 h in 96-well culture plates containing $150 \mu \mathrm{L}$ of liquid $1 \times \mathrm{LB} / \mathrm{Amp}$ solution with $20 \%$ glycerol. M13 forward (-20), and reverse primers were used directly on the bacterial cultures following the PCR protocol of Invitrogen to determine the insert size of clones. PCR products were sequenced using the BigDye version 3.1 cycle sequencing kit and fragments were visualized on an ABI 3100 automated sequencer (Applied Biosystems). Sequences with sufficient flanking regions were selected for primer development using the PRIMER 3 software (Rozen \& Skaletsky 1998). PCR was performed in a total volume of $10 \mu \mathrm{L}$ containing $0.25 \mu \mathrm{L}$ of each primer $(10 \mu \mathrm{M}), 0.5 \mathrm{U}$ Sigma RedTaq DNA polymerase, $1 \mu \mathrm{L}$ each of $\mathrm{MgCl}_{2}(10 \mathrm{~mm}), 1 \times$ PCR buffer, and dNTPs $(200 \mu \mathrm{M}$ of each dNTP), $0.5 \mu \mathrm{L}$ of DNA extract, and $5.5 \mu \mathrm{L}$ doubledistilled water. Thermocycling was performed on a GeneAmpPCR 9700 (Applied Biosystems) with the following two-stage protocol: a denaturation step $\left(94^{\circ} \mathrm{C}\right.$ for $2 \mathrm{~min}$ ), five cycles at an initial high annealing temperature (10 $\mathrm{s}$ at $94{ }^{\circ} \mathrm{C}, 10 \mathrm{~s}$ at the locus-specific annealing temperature, and $30 \mathrm{~s}$ at $72^{\circ} \mathrm{C}$ ) followed by 35 cycles at a lower annealing temperature (10 s at $94{ }^{\circ} \mathrm{C}, 10 \mathrm{~s}$ at the locus-specific annealing temperature, and $30 \mathrm{~s}$ at $72{ }^{\circ} \mathrm{C}$ ). Forward primers were labelled with fluorescent dyes FAM, HEX, and NED. Visualization of the fluorescently labelled PCR products was conducted on an ABI 3100 genetic analyser and allele sizes were scored against an internal GENESCAN-500 (Rox) size standard. Genotypes were obtained using GENESCAN analysis version 3.7 software from Applied Biosystems. Primer tests resulted in the identification of 11 polymorphic microsatellite loci. Using GENEPOP (web version 3.1; Raymond \& Rousset 1995), none of the 45 pairwise comparisons showed significant linkage disequilibrium after applying Bonferroni corrections for multiple tests.

For the variation screen, 29 individuals of L. s. souffia from a wild population in the Schwarzach river in Austria were used. Levels of variability of these loci were moderate to high with three to 14 alleles per locus and expected heterozygosities ranging from 0.38 to 0.90 (Table 1). Two microsatellite loci were found to deviate from HardyWeinberg expectations based on exact tests using GENEPOP. While the positive $F_{\text {IS }}$ for Lsou19 indicates the occurrence of null alleles at this locus, homozygote deficiency was detected at Lsou09. Lsou10 was fixed in L. s. souffia (279 bp), whereas variability was observed in the Italian population 'Parrono' (L.S. muticellus) and four closely related species (Table 2). Testing eight microsatellite primer pairs in closely

Table 1 Eleven microsatellites for Leuciscus souffia based on a sample of 29 individuals from one population in the river Schwarzach in Austria

\begin{tabular}{|c|c|c|c|c|c|c|c|c|c|c|}
\hline Locus & $\begin{array}{l}\text { Fluorescent } \\
\text { dye }\end{array}$ & Primer sequence $\left(5^{\prime}-3^{\prime}\right)$ & Core motif & Size (bp) & $T_{\mathrm{a}}\left({ }^{\circ} \mathrm{C}\right)$ & $N_{\mathrm{A}}$ & $H_{\mathrm{O}}$ & $H_{\mathrm{E}}$ & $F_{\text {IS }}$ & $P$ \\
\hline Lsou05 & HEX & $\begin{array}{l}\text { F: CTGAAGAAGACCCTGGTTCG } \\
\text { R: CCCACATCTGCTGACTCTGAC }\end{array}$ & $(\mathrm{CA})_{17}$ & 178-200 & $60^{\circ} \mathrm{C} / 55^{\circ} \mathrm{C}$ & 6 & 0.759 & 0.745 & -0.018 & 0.259 \\
\hline Lsou08 & HEX & $\begin{array}{l}\text { F: GCGGTGAACAGGCTTAACTC } \\
\text { R: TAGGAACGAAGAGCCTGTGG }\end{array}$ & $(\mathrm{GT})_{17}$ & 187-195 & $62^{\circ} \mathrm{C} / 58^{\circ} \mathrm{C}$ & 5 & 0.552 & 0.640 & +0.140 & 0.619 \\
\hline Lsou09 & FAM & $\begin{array}{l}\text { F: TCGTCAACGAAATTAACACTGG } \\
\text { R: GTCACATGGTCAGGGAAAGG }\end{array}$ & $(\mathrm{GA})_{34}$ & $110-158$ & $60^{\circ} \mathrm{C} / 55^{\circ} \mathrm{C}$ & 14 & 0.920 & 0.904 & $-0.018^{*}$ & $<0.001$ \\
\hline Lsou10 & FAM & $\begin{array}{l}\text { F: ATGAGGGTGATGAGGAGCAG } \\
\text { R: CTCCGTCTGTCTGTCTGTCG }\end{array}$ & $(\mathrm{GT})_{27}$ & 279 & $60^{\circ} \mathrm{C} / 55^{\circ} \mathrm{C}$ & 1 & - & - & - & - \\
\hline Lsou11 & FAM & $\begin{array}{l}\text { F: TCGCAGAAGTTCCTCTGACC } \\
\text { R: GCCGATCAGCATTACCAAAC }\end{array}$ & $(\mathrm{GT})_{13}$ & $262-270$ & $62^{\circ} \mathrm{C} / 58^{\circ} \mathrm{C}$ & 5 & 1.000 & 0.745 & -0.351 & 0.020 \\
\hline Lsou14 & HEX & $\begin{array}{l}\text { F: AGTCGCCCATCTACTGTTGC } \\
\text { R: CGATCAGCAGCTCATTTGC }\end{array}$ & $(\mathrm{GT})_{6} \mathrm{GC}(\mathrm{GT})_{8} \mathrm{GC}(\mathrm{GT})_{10}$ & $232-266$ & $60^{\circ} \mathrm{C} / 55^{\circ} \mathrm{C}$ & 12 & 0.889 & 0.901 & +0.013 & 0.064 \\
\hline Lsou19 & FAM & $\begin{array}{l}\text { F: TCCCGTGGAGAAACTACAGG } \\
\text { R: TTCTTCGGTGAGTGTCGATG }\end{array}$ & $(\mathrm{GT})_{32}$ & $178-218$ & $60^{\circ} \mathrm{C} / 55^{\circ} \mathrm{C}$ & 7 & 0.321 & 0.456 & $+0.300^{*}$ & 0.001 \\
\hline Lsou 21 & FAM & $\begin{array}{l}\text { F: GGCAGGAGGACGTCTATGAG } \\
\text { R: TCATGAAGTCGCTGTGGTTC }\end{array}$ & $(\mathrm{GT})_{13} \mathrm{~N}_{34}(\mathrm{GT})_{8} \mathrm{~N}_{28}(\mathrm{GT})_{10}$ & $281-291$ & $60^{\circ} \mathrm{C} / 55^{\circ} \mathrm{C}$ & 4 & 0.483 & 0.511 & +0.057 & 0.834 \\
\hline Lsou27 & FAM & $\begin{array}{l}\text { F: CGCACTAATGCGTATCGTTG } \\
\text { R: CCTTCCAGCTGATTCAAACG }\end{array}$ & $(\mathrm{GT})_{6} \mathrm{GC}(\mathrm{GT})_{7} \mathrm{GC}(\mathrm{GT})_{10}$ & $197-313$ & $60^{\circ} \mathrm{C} / 55^{\circ} \mathrm{C}$ & 5 & 0.414 & 0.494 & +0.165 & 0.204 \\
\hline Lsou29 & NED & $\begin{array}{l}\text { F: AAAATGATGCTGTGCAATGG } \\
\text { R: CCATCTTTGTCCCCATAACG }\end{array}$ & $(\mathrm{GT})_{10}$ & $311-327$ & $60^{\circ} \mathrm{C} / 55^{\circ} \mathrm{C}$ & 3 & 0.345 & 0.379 & +0.092 & 0.241 \\
\hline Lsou34 & NED & $\begin{array}{l}\text { F: CCAGACAGGGTGATGATTCC } \\
\text { R: GTAGCGACGTTCAGGTCTCG }\end{array}$ & $(\mathrm{GT})_{15}$ & $228-278$ & $62^{\circ} \mathrm{C} / 58^{\circ} \mathrm{C}$ & 10 & 0.724 & 0.826 & +0.126 & 0.009 \\
\hline
\end{tabular}

$T_{\mathrm{a}^{\prime}}$ annealing temperature; bp, base pairs; $N_{\mathrm{A}^{\prime}}$ number of alleles; $H_{\mathrm{O}}$, observed heterozygosity; $H_{\mathrm{E}}$, expected heterozygosity; $F_{\mathrm{IS}}$, fixation index; $P, P$ value for HW test $(\alpha=0.05) ;{ }^{*}$, significant at the Bonferroni corrected significance level $(0.006)$. GenBank Accession nos EF209002-EF209012. 


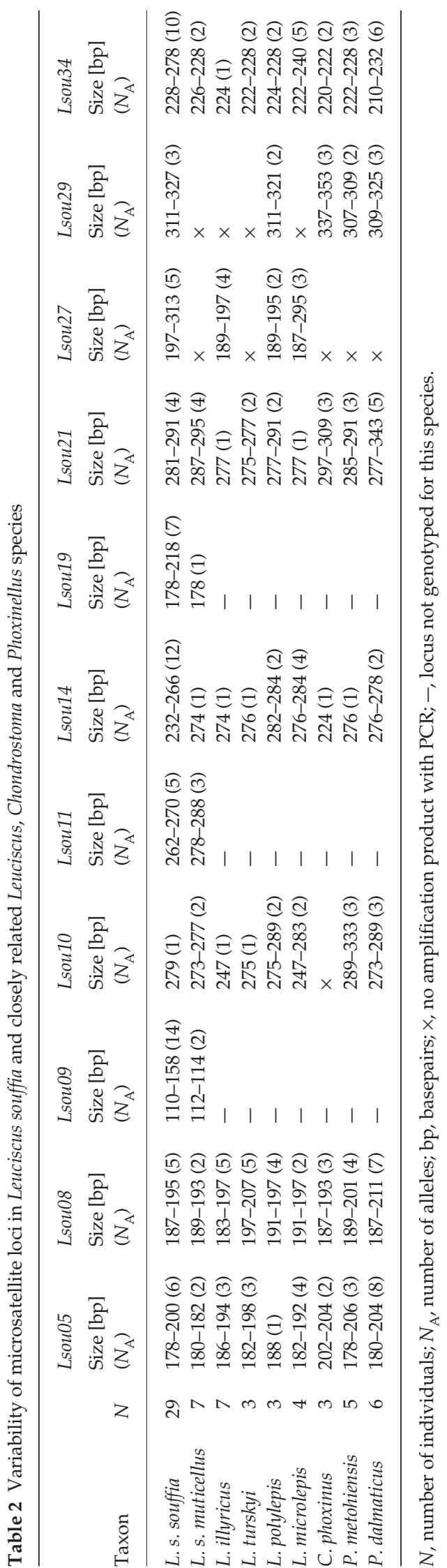

related species demonstrates amplification success with moderate to high levels of heterozygosity at each locus. Additional species tested were Leuciscus illyricus, Leuciscus turskyi, Leuciscus polylepis, Leuciscus microlepis, Chondrostoma phoxinus, Phoxinellus metohiensis, and Phoxinellus dalmaticus. The reason for lack of variability in some related species at some loci might be due to the small sample size investigated (see Table 2). However, the interspecific data indicate that these markers will be a valuable tool for population genetic studies for other cyprinid species as well. Therefore, the reported microsatellites have the potential to become an important tool in future population genetic analyses of these fishes with regard to phylogeographical approaches and conservation issues.

\section{Acknowledgements}

We would like to thank Elke Hespeler and Wanrong Tham for technical assistance, and Jörg Bohlen, Beat Grabherr, and Eugenio Miotti for tissue samples. Financial support was provided by grants of the Deutsche Forschungsgemeinschaft (SFB454, Bodenseelitoral) and the University of Konstanz to A.M., and the Center for Junior Research Fellows of the University of Konstanz to W.S.

\section{References}

Garner TWJ, Gautschi B, Röthlisberger S, Reyer H-U (2000) A set of CA repeat microsatellite markers derived from the pool frog, Rana lessonae. Molecular Ecology, 9, 2173-2175.

Gilles A, Chappaz R, Cavalli L, Lörtscher M, Faure E (1998) Genetic differentiation and introgression between putative subspecies of Leuciscus souffia (Teleostei: Cyprinidae) of the region of the Mediterranean Alps. Canadian Journal of Fisheries and Aquatic Sciences, 55, 2341-2354.

Raymond M, Rousset F (1995) GENEPOP (version 1.2): population genetics software for exact tests and ecumenicism. Journal of Heredity, 86, 248-249.

Rozen S, Skaletsky HJ (1998) PRIMER 3. Available at http:// www.genome.wi.mit.edu/genome_software/other/ primer3.html (accessed on 17 December 2004).

Salducci MD, Martin J-F, Pech N, Chappaz Ret al. (2004) Deciphering the evolutionary biology of freshwater fish using multiple approaches-insights for the biological conservation of the Vairone (Leuciscus souffia souffia). Conservation Genetics, 5, 63-77.

Salzburger W, Brandstätter A, Gilles A et al. (2003) Phylogeography of the vairone (Leuciscus souffia, Risso 1826) in Central Europe. Molecular Ecology, 12, 2371-2386.

Sambrook J, Fritsch EF, Maniatis T (1989) Molecular Cloning: A Laboratory Manual, 3rd edn. Cold Spring Harbor Laboratory Press, Cold Spring Harbor, New York.

Tenzer I, Ivanissevich SD, Morgante M, Gessler C (1999) Identification of microsatellite markers and their application to population genetics of Venturia inaequalis. Phytopathology, 89, 748-753.

Zardoya R, Doadrio I (1999) Molecular evidence on the evolutionary and biogeographical patterns of European cyprinids. Journal of Molecular Evolution, 49, 227-237. 